\title{
Exploring the Relationships among Locus of Control, Work Enthusiasm, Leader-member Exchange, Organizational Commitment, Job Involvement, and Organizational Citizenship Behavior of High-tech Employees in Taiwan
}

\author{
Jung-Wen Hsia ${ }^{1, *}$, Ai-Hua Tseng ${ }^{2}$ \\ ${ }^{1}$ Department of International Business, Chung Hua University, Taiwan \\ ${ }^{2}$ Department of Hospitality Management, Chung Hua University, Taiwan
}

Copyright $(\mathcal{C} 2015$ by authors, all rights reserved. Authors agree that this article remains permanently open access under the terms of the Creative Commons Attribution License 4.0 International License

\begin{abstract}
Due to the rapid development of information technology and global economic competition, high-tech companies face more fierce competitive pressure. If a corporation wants to better compete against his competitors, it would need many highly-qualified workforce to devote all their efforts and resources to solve difficult problems and to achieve organizational goals. Most excellent high-tech companies have devoted many resources to retain qualified and competent employees and to motivate them to increase their performance. However, many high-qualified employees often quit their jobs and then work for other companies. Therefore, it is critical to better understand the important factors influencing employees' organizational commitment, job involvement, and organizational citizenship behavior. According to literature review and interviews with 5 HR managers, the study applied different theories and empirically investigated on the factors that affect organizational commitment, job involvement, and organizational citizenship behavior by integrating locus of control, work enthusiasm, and leader-member exchange into the theoretical model. Data were collected from 201 employees at 6 high-tech companies located in the Hsinchu Science Park, Taiwan. The partial least squares approach was used to evaluate the explanatory power and causal links of the model. Analytical results indicate that leader-member exchange had a significant effect on organizational commitment and job involvement. Work enthusiasm had a direct effect on organizational commitment and job involvement. Locus of control had a direct effect on organizational commitment. Further, organizational commitment and job involvement both influence organizational citizenship behavior. The future research and practical implications of the findings are discussed.
\end{abstract}

Keywords Leader-member Exchange, Locus of Control, Work Enthusiasm, Organizational Commitment, Job Involvement, Organizational Citizenship Behavior

\section{Introduction}

Owing to the rapid development of information technology and global competition, most high-tech companies have faced higher competitive pressure than ever. High-tech industries are very different from traditional industries. Traditional firms generally face a relatively stable and low uncertainty environment. The tasks of traditional organizational employees are generally simple and routine $[1,2]$. In contrast, high-tech firms exist in an environment characterized by rapid change, ambiguity, dynamics, and hyper-competition and they face very short product life cycle and sudden losses in market position $[3,4,5]$. Therefore, most excellent high-tech companies have made all their efforts to find better ways to compete, survive, and success in their business war.

Since high committed employees have strong desires to endeavor on achieving organizational goals and they would have higher job satisfaction and job involvement [6], recruiting and retaining high-qualified, committed human resource is very crucial for a company to compete and win in the keen business competition. In addition, employees with high job involvement or high organizational citizenship behavior (OCB) also will make more contributions to their companies.

Prior research has explored many factors that can affect employees' organizational commitment, job involvement 
and OCB $[7,8,9]$. However, due to the rapid change of the high-tech business environment and the working values and attitudes of employees could also change rapidly in the information age, therefore, we would need more detailed empirical investigation to understand what and how the antecedent factors may influence employees' organizational commitment, job involvement and OCB.

The study intends to integrate personality factor (locus of control), attitude factor (work enthusiasm), and social exchange factor (leader-member exchange, LMX) into one model. The study first examines the effects of locus of control, work enthusiasm, and LMX on organizational commitment and job involvement. Next, this study examines the influence of organizational commitment and job involvement on OCB. Hence, this study aims to make an important contribution by identifying appropriate factors that can influence high-tech employees' important work attitudes.

\section{Literature Review and Research Model}

The theoretical model underpinning this study is shown in Figure 1. The model suggests that locus of control, work enthusiasm, and LMX all serve as antecedents of organizational commitment and job involvement. Next, organizational commitment and job involvement both server as antecedents of OCB. The following sections will discuss the proposed relationships among these constructs.

\subsection{Locus of Control}

In organizational research, locus of control has been defined as the degree to which one perceives events as under one's own control (internal locus) or under the control of others (external locus) [10]. Individuals with a strong internal locus of control are called internals. Conversely, individuals with a strong external locus of control are called externals. Due to internals perceive themselves to have greater control over the environment, they will exert great efforts to reach their goals and then they tend to more success in recognition, salary increase, and promoted in their organization than externals. Thus, it might be expected that individuals with internal locus of control would have higher levels of job involvement and organizational commitment than individuals with external locus of control.

Prior research has been done on the influence of locus of control on organizational commitment and job involvement $[11,12,13]$. Therefore, the study proposes the following hypotheses.

H1: Internal locus of control positively affects organizational commitment.

$\mathrm{H} 2$ : Internal locus of control positively affects job involvement.

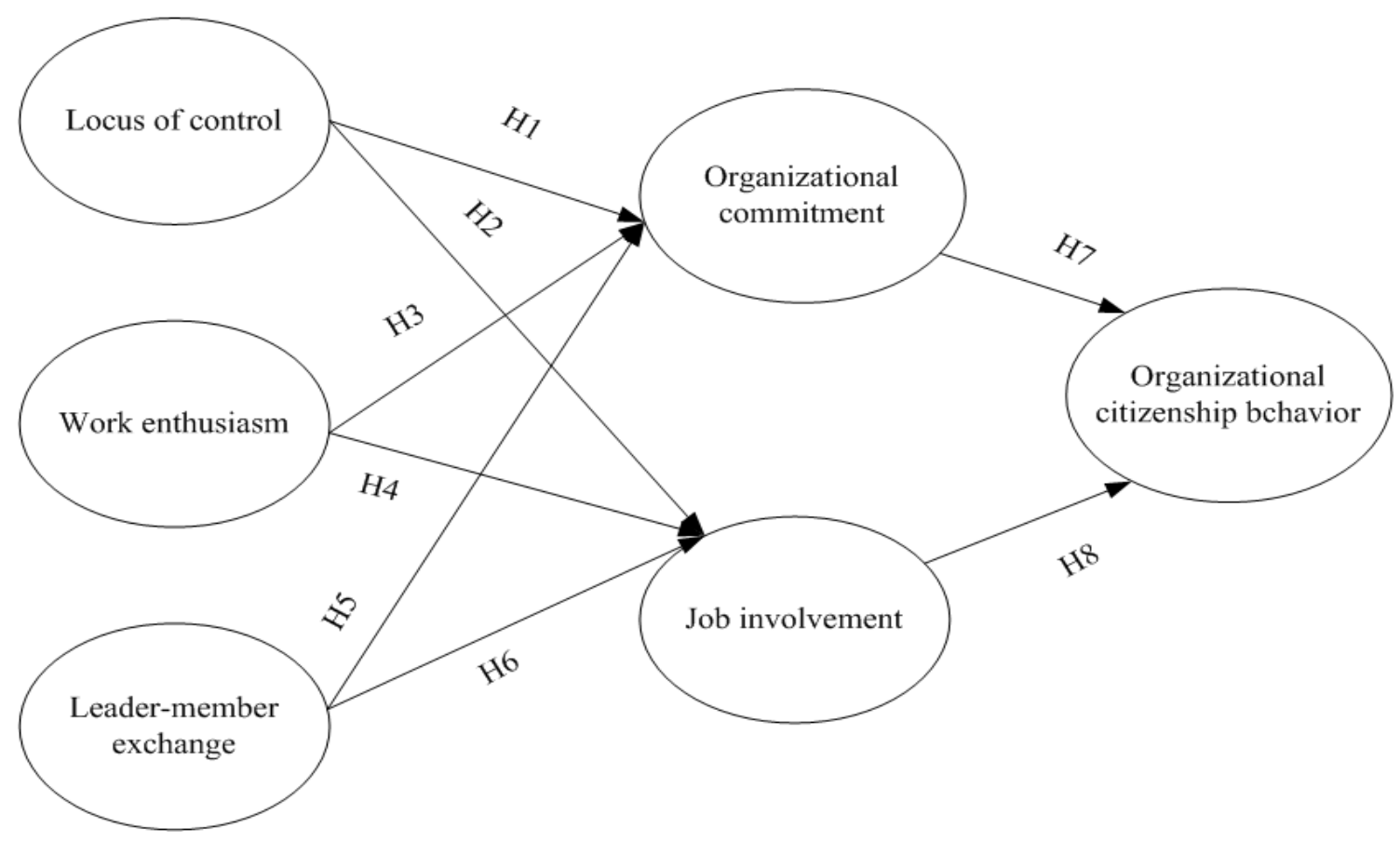

Figure 1. Research model. 


\subsection{Work Enthusiasm}

Work enthusiasm is defined as extroverted, goal-oriented, various modes of interpersonal relationship, handle changes well, and enjoy new and different challenges on the job [14]. Work enthusiasm is an important factor influencing employees' work attitudes and behaviors. The enthusiastic employees are generally expected to be energized and active. They are more likely to express their passion for job $[15,16]$. Smith [17] argued that if an individual have high level of Work enthusiasm, he/she will endeavor all his/her effort to strive for excellent performance.

Enthusiastic employees will have more job satisfaction and spend more time on their work without any external rewards [18]. As Dik and Duffy [19] indicated there is a significant relationship between low job enthusiasm and low organizational commitment. However, surprisingly less research has examined the effect of work enthusiasm on job involvement. Thus, the study proposes the following hypotheses.

H3: Work enthusiasm positively affects organizational commitment.

H4: Work enthusiasm positively affects job involvement.

\subsection{Leader-member Exchange}

LMX refers to the quality of the exchange relationship that develops between employees and supervisors [20]. Due to supervisors' resources and time is usually limited, they would choose trusted and liked subordinates to share most of his/her valuable resources [21]. Then these enhanced resources will lead high LMX subordinates to increase their positive work attitudes such as job involvement and organizational commitment.

Prior research has investigated the relationships between LMX and organizational commitment and job involvement $[22,23,24]$. For instance, Wayne and his colleagues reviewed 23 studies and they found a positive relationship between LMX and affective organizational commitment [25]. In an empirical study by Lawrence and Kacmar [26], LMX has a direct influence on job involvement. Thus, the study proposes the following hypotheses.

H5: Leader-member exchange positively affects organizational commitment.

H6: Leader-member exchange positively affects job involvement.

\subsection{Organizational commitment, Job Involvement, and OCB}

Organizational commitment had been defined as "the relative strength of an individual's identification with and involvement in an organization" [27]. Generally speaking, organizational commitment is a stable attitude, which can influence and maintain individual's positive behavioral direction in his/her organization. That is, since OCB represents behavior that go beyond the individual's formal obligations [28], organizational commitment represents a relevant determinant. Further, prior research has been empirically examined the influence of organizational commitment on OCB [29].

Job involvement is defined as the extent to which the individual identifies psycho- logically with his/her job [30]. Job involvement is considered to be a critical factor influencing important individual outcomes and it could be a primary determinant of individual motivation $[31,32]$. In general, people with high levels of job involvement are likely to put more effort into their jobs and would like to create a better working environment. Hence, they might tend to display higher levels of OCB. Empirically, prior research has been investigated the relationship between job involvement and OCB [33]. According to these arguments, this study proposes the following hypotheses.

H7: Organizational commitment positively affects OCB.

H8: Job involvement positively affects OCB.

\section{Methodology}

\subsection{Measures}

All research variables were measured using multi-item scales. To ensure the content validity of the scales, the items selected must represent the concept in order to generalize in another context [34]. Items selected for the constructs of the research mainly adapted from prior studies to ensure content validity.

The scales for organizational commitment were measured by 4 subscales of Meyer, Allen, and Smith' [35] commitment scales. Job involvement was measured by using 4 items which were taken from Kanungo's Job Involvement Questionnaire [36,37]. OCB was measured with 5 items which were taken from a Chinese OCB scale of Farh, Earley and Lin [38].

Locus of control was measured with a 5-item subset of abbreviated version [39] of Rotter's [10] general measure of locus of control was administrated. LMX was measured by using 5 items of Scandura and Graen [40]' LMX scale. Work enthusiasm was measured by 5 items and adapted from Lee and Lin [14]' work. All above items were scored on a Likert scale from 1 to 5 , with a 1 rating indicating strong disagreement and a 5 rating indicating strong agreement.

\subsection{Subjects}

The study used nonrandom sampling technique (i.e., convenience sampling) to collect data [41]. A questionnaire was designed and sent to high-tech companies chosen for the study. Data for this study were collected mainly from 6 high-tech companies in the Hsinchu Science Park in Taiwan. The respondents completed self-reported questionnaires. A total of 280 surveys were distributed and a total of 211 
responses $(75.4 \%)$ were received. Due to missing data and outliers we obtained an effective response rate of $n=201$ $(71.8 \%)$.

The individual respondents averaged 34 years of age and had 3.5 years of experience in their present company. Ninety-one percent had completed one college or university degree. They work in a wide range of functional areas including technical fields, such as operations and production, $\mathrm{R} \& \mathrm{D}$, and engineering (43.8\%), marketing and sales (19.4\%), accounting and finance $(26.9 \%)$, personnel and general management $(7.3 \%)$, and others $(2.6 \%)$.

\subsection{Data Analysis}

Partial least squares (PLS) was conducted to test the research model. PLS is a structural equation modeling (SEM) technique and it can simultaneously examine the measurement model and the structural model in one model [42]. PLS is more appropriate in research areas where theory is not as well developed as that demanded by LISREL [43]. Since less research has been integrated work enthusiasm, locus of control, and LMX into one model, it is appropriate to use PLS in the study.

\section{Findings}

\subsection{Assessment of the Measurement Model}

Psychometric properties of the scales were assessed in terms of internal consistency, convergent validity, and discriminant validity. The study used composite reliability values (CR) and Cronbach's alpha coefficients to assess reliability and internal consistency of constructs. The results in Table 1 show that all CR and Cronbach's alpha coefficients exceeded the 0.70 threshold suggested by Bagozzi and Yi [44]. The results showed that all constructs exhibited adequate internal consistency and reliability.

Table 1. Assessment of the measurement model

\begin{tabular}{ccc}
\hline Variables & Cronbach' $\alpha$ & CR \\
\hline Locus of control (LOC) & 0.77 & 0.85 \\
Work enthusiasm (WE) & 0.87 & 0.91 \\
Leader-member exchange (LMX) & 0.88 & 0.91 \\
Job involvement (JI) & 0.77 & 0.85 \\
Organizational commitment (OC) & 0.86 & 0.90 \\
Organizational citizenship behavior & 0.78 & 0.85 \\
(OCB) & \\
\hline
\end{tabular}

To evaluate discriminant and convergent validity, the study examined whether all items loaded greater than 0.7 on their respective construct. Cross-loadings of items are given in Table 2. Due to low factor loading for item LOC3 and WE5, the study dropped the two items and rerun. The modified loadings show a clear discriminant and convergent validity for all constructs. Table 2 also demonstrates satisfactory convergent validity since average variance extracted (AVE) for all constructs exceeded 0.50 [45].

Table 2. AVE and PLS cross-loadings: convergent and discriminant validity

\begin{tabular}{|c|c|c|c|c|c|c|}
\hline & LOC & $\mathrm{OCB}$ & LMX & JI & WE & $\mathrm{OC}$ \\
\hline AVE & 0.59 & 0.53 & 0.68 & 0.59 & 0.71 & 0.70 \\
\hline LOC1 & 0.75 & 0.42 & 0.27 & 0.22 & 0.49 & 0.46 \\
\hline LOC2 & 0.85 & 0.42 & 0.30 & 0.22 & 0.62 & 0.48 \\
\hline LOC4 & 0.70 & 0.35 & 0.36 & 0.25 & 0.54 & 0.40 \\
\hline LOC5 & 0.76 & 0.38 & 0.25 & 0.21 & 0.54 & 0.41 \\
\hline OCB1 & 0.46 & 0.73 & 0.28 & 0.26 & 0.33 & 0.26 \\
\hline OCB2 & 0.29 & 0.76 & 0.42 & 0.50 & 0.34 & 0.38 \\
\hline OCB3 & 0.24 & 0.71 & 0.40 & 0.50 & 0.28 & 0.27 \\
\hline OCB4 & 0.58 & 0.71 & 0.24 & 0.27 & 0.41 & 0.31 \\
\hline OCB5 & 0.40 & 0.72 & 0.27 & 0.28 & 0.39 & 0.41 \\
\hline LMX1 & 0.28 & 0.36 & 0.75 & 0.59 & 0.30 & 0.39 \\
\hline LMX2 & 0.21 & 0.32 & 0.84 & 0.52 & 0.27 & 0.36 \\
\hline LMX3 & 0.31 & 0.35 & 0.88 & 0.60 & 0.39 & 0.44 \\
\hline LMX4 & 0.38 & 0.41 & 0.80 & 0.52 & 0.40 & 0.44 \\
\hline LMX5 & 0.38 & 0.45 & 0.85 & 0.54 & 0.41 & 0.43 \\
\hline JI1 & 0.20 & 0.41 & 0.47 & 0.76 & 0.29 & 0.34 \\
\hline J12 & 0.28 & 0.45 & 0.61 & 0.81 & 0.31 & 0.36 \\
\hline $\mathrm{JI} 3$ & 0.20 & 0.35 & 0.47 & 0.73 & 0.24 & 0.18 \\
\hline JI4 & 0.21 & 0.40 & 0.50 & 0.77 & 0.32 & 0.33 \\
\hline WE1 & 0.66 & 0.39 & 0.38 & 0.33 & 0.87 & 0.57 \\
\hline WE2 & 0.55 & 0.33 & 0.36 & 0.34 & 0.79 & 0.46 \\
\hline WE3 & 0.58 & 0.42 & 0.37 & 0.28 & 0.85 & 0.55 \\
\hline WE4 & 0.61 & 0.45 & 0.33 & 0.33 & 0.87 & 0.55 \\
\hline $\mathrm{OC} 1$ & 0.31 & 0.32 & 0.39 & 0.38 & 0.43 & 0.76 \\
\hline $\mathrm{OC} 2$ & 0.42 & 0.37 & 0.43 & 0.30 & 0.46 & 0.81 \\
\hline OC3 & 0.56 & 0.42 & 0.43 & 0.35 & 0.60 & 0.92 \\
\hline $\mathrm{OC} 4$ & 0.56 & 0.39 & 0.41 & 0.32 & 0.61 & 0.84 \\
\hline
\end{tabular}

Further, Table 3 also presents satisfactory discriminant validity as the square root of the AVE is larger than the inter-construct correlations [46]. Due to above analyses exhibited adequate internal consistency, convergent validity, and discriminant validity, hence, the results indicated acceptable psychometric properties.

Table 3. Correlations of Construct and square root of AVE

\begin{tabular}{ccccccc}
\hline & LOC & OCB & WE & LMX & OC & JI \\
\hline LOC & $\mathbf{0 . 7 7}$ & & & & & \\
OCB & 0.51 & $\mathbf{0 . 7 3}$ & & & & \\
WE & 0.65 & 0.47 & $\mathbf{0 . 8 5}$ & & & \\
LMX & 0.37 & 0.46 & 0.43 & $\mathbf{0 . 8 3}$ & & \\
OC & 0.55 & 0.45 & 0.63 & 0.49 & $\mathbf{0 . 8 4}$ & \\
JI & 0.29 & 0.53 & 0.38 & 0.67 & 0.41 & $\mathbf{0 . 7 7}$ \\
\hline
\end{tabular}

Note: Diagonal bold elements were the square root of AVE. 


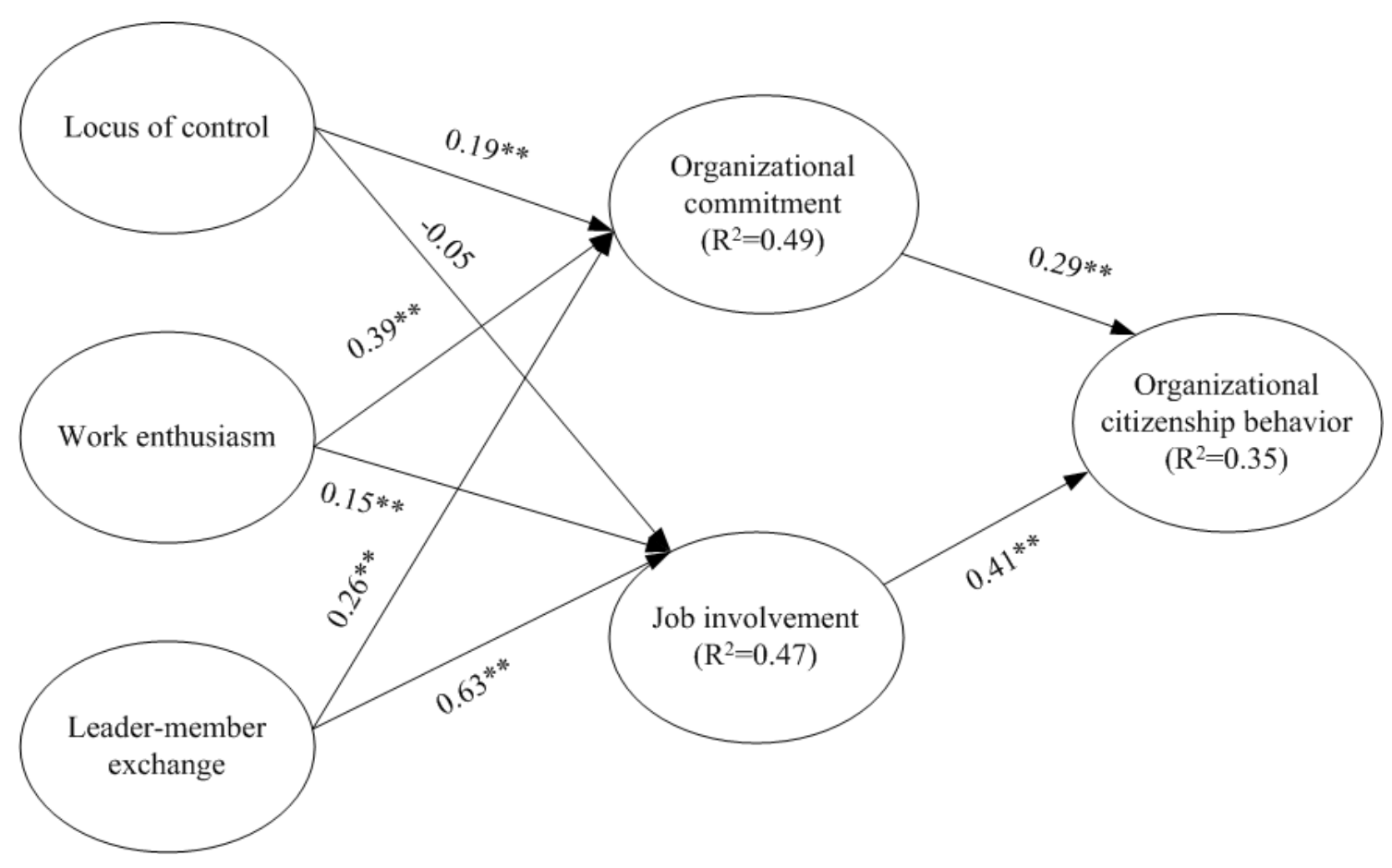

Figure 2. Model parameters for the research model: $* * \mathrm{P}<0.05$.

\subsection{Assessment of the Structural Model}

The PLS estimation results for the structural model are shown in Fig. 2. The estimated path effects ( $\beta$ value), levels of significance (P value), and explained variance $\left(R^{2}\right.$ value) using a bootstrapping procedure. To evaluate the full model, the resulting structural model shows $\mathrm{R}^{2}$ of 0.49 for organizational commitment, $\mathrm{R}^{2}$ of 0.47 for job involvement, and $\mathrm{R}^{2}$ of 0.35 for OCB.

As can be seen, the results showed that locus of control had a significant effect on organizational commitment $(\beta=0.19, \quad \mathrm{P}<0.05)$, however, locus of control had no significant effect on job involvement. Thus, just $\mathrm{H} 1$ was supported. Work enthusiasm had a significant effect on organization commitment $(\beta=0.39, \quad \mathrm{P}<0.05)$ and job involvement $(\beta=0.15, \mathrm{P}<0.05)$. Both $\mathrm{H} 3$ and $\mathrm{H} 4$ were supported. Further, LMX had a significant effect on organization commitment $(\beta=0.26, \quad \mathrm{P}<0.05)$ and job involvement $(\beta=0.63, \mathrm{P}<0.05)$. Therefore, $\mathrm{H} 5$ and $\mathrm{H} 6$ also were supported. Finally, organizational commitment had a significant effect on $\operatorname{OCB}(\beta=0.29, \quad \mathrm{P}<0.05)$ and job involvement also had a significant effect on OCB $(\beta=0.41$, $\mathrm{P}<0.05$ ). Both $\mathrm{H} 7$ and $\mathrm{H} 8$ were supported.

\section{Limitations and Future Studies}

Research findings must be considered in light of limitations. First, as this study used a snapshot approach, a longitudinal approach should be considered in future research. Second, since this study used relatively small sample to testify this model, future study can use a larger sample size to improve the generalization of research findings.

\section{Conclusion and Implications}

This study is to investigate the influence of locus of control, work enthusiasm, and LMX on high-tech employees' organizational commitment, job involvement, and OCB. Although there was no effect of locus of control on job involvement, other hypotheses were supported.

The findings of this study can enhance our understanding how these antecedent factors can affect the levels of employees' important attitudes such as organizational commitment, job involvement and OCB. By understanding how these factors influence employees' work attitude, managers can better inspire and retain highly-qualified employees. For example, supervisors can use many methods such as delegation and empowerment to increase their LMX with subordinates. These efforts can increase employees' job involvement and organizational commitment.

Further, owing to less research has integrated personality factor (locus of control), attitude factor (work, enthusiasm), and social exchange factor (LMX) in one model, the study also provides valuable contributions for organizational behavior and human resource management research.

\section{REFERENCES}

[1] Harpaz I, Meshoulam I. Differences in the meaning of work in Israel: Workers in high-tech versus traditional work industries. The Journal of High Technology Management Research. 2004;15(2):163-182.

[2] Hodson R. Working in "High-Tech" : Research issues and 
opportunities for the industrial sociologist. The Sociological Quarterly. 1985;26(3):351-364.

[3] Collins CJ, Clark KD. Strategic human resource practices, top management team social networks, and firm performance: The role of human resource practices in creating organizational competitive advantage. Academy of management Journal. 2003;46(6):740-751.

[4] Miles RE, Snow CC. Designing strategic human resources systems. Organizational dynamics. 1984;13(1):36-52.

[5] Qian G, Li L. Profitability of small - and medium - sized enterprises in high - tech industries: the case of the biotechnology industry. Strategic Management Journal. 2003;24(9):881-887.

[6] Bennett H, Durkin M. The effects of organisational change on employee psychological attachment An exploratory study. Journal of Managerial Psychology. 2000;15(2):126-146.

[7] Brown SP. A meta-analysis and review of organizational research on job involvement. Psychological Bulletin. 1996;120(2):235-255.

[8] Eisenberger R, Fasolo P, Davis-LaMastro V. Perceived organizational support and employee diligence, commitment, and innovation. Journal of Applied Psychology. 1990;75(1): $51-59$.

[9] Mathieu JE, Zajac DM. A review and meta-analysis of the antecedents, correlates, and consequences of organizational commitment. Psychological Bulletin. 1990;108(2):171-194.

[10] Rotter JB. Generalized expectancies for internal versus external control of reinforcement. Psychological Monographs: General and Applied. 1966;80(1):1-28.

[11] Kinicki AJ, Vecchio RP. Influences on the quality of supervisor-subordinate relations: The role of time-pressure, organizational commitment, and locus of control. Journal of Organizational Behavior. 1994;15(1):75-82.

[12] Singh AP, Nath K. Effects of Organisational Climate, Role Stress and Locus of Control on Job Involvement of Banking Personnel. Indian Journal of Industrial Relations. 1991;27(2):63-76.

[13] Spector PE. Behavior in organizations as a function of employee's locus of control. Psychological Bulletin. 1982;91(3):482-497.

[14] Lee HW, Lin MC. A study of salary satisfaction and job enthusiasm-mediating effects of psychological contract. Applied Financial Economics. 2014;24(24): 1577-1583

[15] Hanson M, Hanson M. Passion and Purpose, Pathfinder, Alameda, CA; 2002

[16] Suliman AM. Work performance: is it one thing or many things? The multidimensionality of performance in a Middle Eastern context. International Journal of Human Resource Management. 2001;12(6);1049-1061.

[17] Smith P. Pursuing passion, New Zealand Management. 2000;47;94-97.

[18] Wrzesniewski A, McCauley C, Rozin P, Schwartz B. Jobs, careers, and callings: People's relations to their work. Journal of Research in Personality. 1997;31(1):21-33.

[19] Dik BJ, Duffy RD. Calling and vocation at work definitions and prospects for research and practice. The Counseling Psychologist. 2009;37(3):424-450.

[20] Liden RC, Sparrowe RT, Wayne SJ. Leader-member exchange theory: The past and potential for the future. Research in Personnel and Human Resources Management. 1997;15:47-119.

[21] Liden RC, Graen G. Generalizability of the vertical dyad linkage model of leadership. Academy of Management Journal. 1980;23(3):451-465.

[22] Cheung $\mathrm{M} \mathrm{F}$, Wu WP. Leader-member exchange and employee work outcomes in Chinese firms: the mediating role of job satisfaction. Asia Pacific Business Review. 2012;18(1):65-81.

[23] Kang DS, Stewart J, Kim H. The effects of perceived external prestige, ethical organizational climate, and leader-member exchange (LMX) quality on employees' commitments and their subsequent attitudes. Personnel Review. 2011; 40(6):761-784.

[24] Wittmer JL, Martin JE, Tekleab AG. Procedural Justice and work outcomes in a unionized setting: the mediating role of leader-member exchange. American Journal of Business. 2010;25(2):55-70.

[25] Wayne SJ, Coyle-Shapiro JAM, Eisenberger R, Liden RC, Rousseau DM, Shore LM. Social influences. In H. J. Klein, T. E. Becker, \& J. P. Meyer (Eds.), Commitment in organizations: Accumulated wisdom and new directions (pp. 253-284). New York, NY: Taylor \& Francis; 2009.

[26] Lawrence ER, Kacmar KM. Leader-member exchange and stress: The mediating role of job involvement and role conflict. Journal of Behavioral and Applied Management. 2012;14(1):39-52.

[27] Mowday R, Porter L, Steers R. Organizational linkages: The psychology of commitment, absenteeism, and turnover. New York: Academic Press; 1982.

[28] Organ DW. Organizational citizenship behavior: The good soldier syndrome. Lexington Books/DC Heath and Com; 1988.

[29] Williams LJ, Anderson SE. Job satisfaction and organizational commitment as predictors of organizational citizenship and in-role behaviors. Journal of Management. $1991 ; 17(3): 601-617$

[30] Blau GJ. A multiple study investigation of the dimensionality of job involvement. Journal of Vocational Behavior. 1985;27(1):19-36.

[31] Hackman JR, Lawler EE. Employee reactions to job characteristics. Journal of Applied Psychology. 1971;55(3):259-286.

[32] Lawler III EE. High-Involvement Management. Participative Strategies for Improving Organizational Performance. Jossey-Bass Inc., Publishers, San Francisco; 1986

[33] Diefendorff JM, Brown DJ, Kamin AM, Lord RG. Examining the roles of job involvement and work centrality in predicting organizational citizenship behaviors and job performance. Journal of Organizational Behavior. 2002;23(1):93-108.

[34] Bohmstedt GW. Reliability and validity assessment in attitude measurement. In: G.F. Summers (ed.), Attitude Measurement. 
Chicago: Rand-McNally, 80-99; 1970.

[35] Meyer JP, Allen NJ, Smith CA. Commitment to organizations and occupations: Extension and test of a three-component conceptualization. Journal of Applied Psychology. 1993;78(4):538-551.

[36] Kanungo RN. Measurement of job and work involvement. Journal of Applied Psychology. 1982a;67(3): 341-349.

[37] Kanungo RN. Work alienation: An integrative approach. New York: Wiley; 1982b.

[38] Farh JL, Cheng BS. An investigation of modesty bias in self-ratings of work performance among Taiwanese workers. Chinese Journal of Psychology. 1997;39(2):75-92. (In Chinese).

[39] Valecha GK, Ostrom TM. An abbreviated measure of internal-external locus of control. Journal of Personality Assessment. 1974;38(4):369-376.

[40] Scandura TA, Graen GB. Moderating effects of initial leadermember exchange status on the effects of a leadership intervention. Journal of Applied Psychology.
$1984 ; 69(3): 428-436$.

[41] Creswell JW. Educational research: Planning, conducting, and evaluating quantitative(4th ed.) Upper Saddle River, NJ: Pearson Education; 2002.

[42] Bollen K. Structural equations with latent variables. New York: Wiley-Interscience; 1989.

[43] Fornell C, Bookstein F. Two structural equation models: LISREL and PLS applied to consumer exit-voice theory. Journal of Marketing Research. 1982;19(4):440-452.

[44] Bagozzi RP, Yi Y. On the evaluation of structural equation models. Journal of the Academy of Marketing Science. 1988;16(1):74-94.

[45] Fornell C, Larcke DF. Evaluating structural equation models with unobserved variables and measurement error. Journal of Marketing Research. 1981;18(1):39-50.

[46] Chin WW. The partial least squares approach to structural equation modeling. In G. A. Marcoulides (Ed.), Modern methods for business research (pp. 295-336). Mahwah, NJ: Lawrence Erlbaum Associates; 1998. 